\title{
Making medicine a business in Japan: Shimadzu Co. and the diffusion of radiology (1900-1960)*
}

Pierre-Yves Donzé

\section{Summary}

This contribution focuses on the role of the firm Shimadzu in the marketing of X-ray machines in Japan during the first part of the 20th century, viewed from a business history perspective. It attempts to further understanding of the process of technology diffusion in medicine. In a global market controlled by American and German multinational enterprises, Japan appears to have been a particular country, where a domestic independent firm, Shimadzu, succeeded in establishing itself as a competitive company. This success is the result of a strategy based on both the internalisation of technological capabilities (recruitment of university graduate engineers, subcontracting of research and development activities) and an original communication policy towards the medical world. Finally, the specific structure of the Japanese medical market, composed of numerous and largely privatised small healthcare centres, facilitated the rapid diffusion of X-ray machines, a new technology which conferred a comparative advantage on its holders.

Keywords: radiology; technology; Japan; Shimadzu

\section{Introduction}

Radiology played a key role in the process which made medicine a moneymaking business during the first part of the 20th century ${ }^{1}$. On the one hand, it contributed, together with drugs produced by the pharmaceutical industry

* This work was supported by Grant-in-Aid for Japan Society for the Promotion of Science Fellow (21-09015). I would like to thank Vincent Barras for his comments and advice on a former draft of the paper.

1 The business history of medicine is a field paradoxically not very developed considering the economical importance of this sector: Donzé 2005. About radiology in general, see Holtzmann Kevles 1997.

Pierre-Yves Donzé, Osaka University, Graduate School of Economics (py.donze@gmail.com). 
and the first medical laboratories, to making medicine an innovation-based and steadily growing economical activity ${ }^{2}$. On the other hand, the particular importance of radiology lies in the fact that it is an infrastructure with a major impact on the organisation and management of hospitals. Research carried out, especially on American and Swiss cases, highlights the essential role of radiology equipment in the transformation of hospitals into organisations managed like modern enterprises and their insertion in the heart of the healthcare market ${ }^{3}$.

In the case of Japan, this change took place in a specific context - that of the transformation of the domestic healthcare system as a result of the spread of Western medicine ${ }^{4}$. When the first X-ray machines appeared in Japanese hospitals during the 1900s, the transition of the medical system to the Western model was well under way. The opening of the Faculty of Medicine of Tokyo University (1877), the founding of a growing number of hospitals (63 in 1875 and 783 in 1900) $)^{5}$, as well as the adoption of a law on the practice of medicine which legalised the hierarchy between the different kinds of practitioners $(1907)^{6}$ made it possible for the Western model, essentially German, to take root in Meiji Japan. To date, only a limited number of works have been devoted to the transformation of the Japanese healthcare system tackled from a technology history and business history perspective. The question of drugs, an important part of the business of medicine, has been covered by scholars focusing on the shift from the production of traditional medicine towards Western industrially manufactured products and the permanence of Japanese pharmaceutical enterprises within this process ${ }^{7}$. As for the problem of infrastructure and equipments, it hardly caught the attention of researchers, except the works of Ikai on the structure of the hospital market ${ }^{8}$ and of Tsukisawa on the introduction of German medical instruments into Japan during the $1870 \mathrm{~s}^{9}$.

The objective of this paper is to analyse, through the example of X-ray machines, the way new Western medical technologies were introduced, diffused and developed in Japan. As with drugs, there are a few rare cases of

\footnotetext{
2 Blume 1992; Löwy 1993; Stanton 1999; Pickstone 2000; Stanton 2002 (particularly her introduction, 1-18).

3 Rosner 1982; Howell 1995; Donzé 2007.

4 Shinmura 2006.

5 Nihon choki tokei 2006, vol. 5, 170.

6 This law (ishiho) classified the different kinds of doctors into three categories, with the one holding a Japanese doctorate degree (hakasego) or a foreign $\mathrm{PhD}$ on the top of the hierarchy, and doctors practicing traditional medicine at the bottom. Shinmura 2006, 255.

7 Yongue 2005; Yamashita 2010.

8 Ikai 2010.

9 Tsukisawa 2009.
} 
continuity from the Edo period onto the 20th century, with the shift from the production of traditional medicines to the manufacturing of medical instruments, including X-ray machines, as can be seen from the example of the Osaka-based company Shiraimatsu. But these examples are too uncommon to be representative of a general trend ${ }^{10}$. Rather, new enterprises appear to have been the main producers of these machines which changed modern medicine, especially American (General Electric, Westinghouse Electric) and German (Siemens,AEG) multinational enterprises that very soon dominated the world market, including Japan. Yet beside these global firms, there were also several independent domestic firms that contributed to the diffusion of $\mathrm{X}$-ray machines and radiology in the country, among which the biggest was Shimadzu Corporation, the subject of this contribution. The focus is on the strategies adopted by this enterprise in order to establish itself alongside the powerful foreign multinationals as a key actor of medicine business in Japan during the first part of the 20th century.

\section{The beginnings (1900-1914)}

The company Shimadzu Corporation (Shimadzu seisakujo) was founded at Kyoto in 1875 by Shimadzu Genjo (1839-1894) as a workshop specialised in the manufacture of scientific instruments primarily meant for schools ${ }^{11}$. This industrial activity resulted from a change in education policy, with the spread of a Western-style educational system that led to new needs. For launching out into this business, Shimadzu benefitted from traditional crafts know-how, as his father owned a workshop for manufacturing Buddhist worship objects where he worked for several years, on the one hand, and from the support of a chemical and physics research institute (Kyoto seimikyoku) set up in 1870 by the authorities of Kyoto prefecture ${ }^{12}$. This external backing, particularly through a German engineer who taught there, enabled Shimadzu to embark upon the production of a whole series of new instruments and devices for schools.

Nevertheless, it was especially the second generation homonym owner, Shimadzu Genzo II (1869-1951), who made the family workshop an industrial firm diversified in new sectors, including medicine. Two years after having taken over the management of the firm following his father's death,

10 Shiraimatsu 2002.

11 Shimadzu 1967,1.

12 Shimadzu 1967,2. 
he took the first X-ray in Japan $(1896)^{13}$. This was made possible thanks to his collaboration with a physicist, Muraoka Hanichi (1853-1929). Between 1878 and 1881, Muraoka studied physics at the University of Strasbourg, where he obtained a PhD and where he met with Wilhelm Roentgen, assistant professor in the university at the time. After returning to Japan, Muraoka held several academic positions, including that of physics teacher at Kyoto Third High School from 1893 onwards $^{14}$. The realisation of this first X-ray image was most certainly both a scientific and a promotional success for Shimadzu. Shortly thereafter, he developed a first X-ray machine for teaching $(1897)^{15}$. Subsequently, these devices were designed for the traditional market of the firm - schools - for physics teaching ${ }^{16}$. It took some ten more years to shift from a scientific device to a medical appliance. Indeed, it was not until the end of the 1900s that Shimadzu produced its first X-ray machines for medical practice. First, German companies, mainly Siemens ${ }^{17}$, enjoyed a virtual monopoly in terms of X-ray machines for hospitals. Despite this stiff competition, Shimadzu developed an X-ray machine for medical purposes in $1908^{18}$, subsequently delivering such devices to Konodai Military Hospital (1909) and Otsu Japanese Red Cross Hospital (1911) ${ }^{19}$. In addition, the first private hospitals ordered similar appliances in $1910^{20}$. However, Shimadzu truly established itself on this new market during World War I.

\section{Towards the medical appliance manufacturing firm (1914-1945)}

World War I appears as a real breakthrough with regard to the market for $\mathrm{X}$-ray machines in Japan, for political and technological reasons. First, as was the case with other sectors of the economy, the war put an end to economic relations with Germany ${ }^{21}$. Imports of German goods were not only halted overnight, but the holdings of German companies, especially patents, were seized by the Japanese authorities as well. In the case of X-ray machines, the abrupt disappearance of German firms, which totally controlled this market until 1914, enabled Japanese companies, including Shimadzu, to embark

13 Shimadzu 1967, 16.

14 Shimadzu 1967, 16.

15 Goto $1969,18$.

16 Shimadzu 1967, 353.

17 Med-Archiv, Erlangen (Germany), 7912, Chronology of Siemens-Schuckert D.D.K., Tokyo, February 1944.

18 Goto $1969,64$.

19 Shimadzu 1967, 18.

20 Shimadzu 1967,353.

21 On the relationships between Japan and Germany, see Kudo/Tajima/Pauer 2009. 
upon this activity. It was precisely in 1915 that Shimadzu marketed its first mass-produced X-ray machine for medical purposes, the A model ${ }^{22}$.

Next, one should mention a major technological innovation realised in the United States, in the laboratory of the multinational enterprise General Electric Co (GE): the development of the Coolidge X-ray tube (1913) ${ }^{23}$. The particularities of this tube (high vacuum; tungsten spiral filaments for heating) allowed for easy control of the dosage of rays by making their volume (current) independent from their penetrative power (voltage). This breakthrough made possible an excellent application of radiology to medicine and facilitated its speedy diffusion. In Japan, this technology was controlled by Tokyo Electric Co, a GE-affiliate founded in 1905. It had a monopoly on imports and sales of Coolidge tubes in Japan, then their manufacture from 1920 onwards $^{24}$. Yet up until the early 1930s, GE did not produce complete $\mathrm{X}$-ray appliances but only tubes, which were sold to appliance makers. However, the American multinational was not the sole tube producer, even if its tubes were of top quality. GE's main rivals were German companies, as well as several Japanese manufacturers producing lower-quality copies (Kinzawa Medical Appliances Co, Shibuya Roentgen Co ${ }^{25}$. Shimadzu approached Tokyo Electric and used Coolidge tubes for its machines from 1917 onwards ${ }^{26}$. The two firms even signed an agreement in 1922, thereby ensuring the supply for Shimadzu ${ }^{27}$. This situation lasted until the beginning of the 1930s. As the patent for Coolidge tubes expired in 1934, GE and Tokyo Electric planned at the time to diversify into the production of complete X-ray equipment with the launch in 1932 of the Giba 75 appliance, the mainstay of Tokyo Electric's competitiveness on this market ${ }^{28}$. As for tube production, many newcomers entered the market after $1934^{29}$.

Accordingly, for some twenty years, from World War I to the beginning of the 1930s, Shimadzu took advantage of favourable conditions to establish itself as an X-ray machine producer in Japan. The absence of German competitors, followed by the collaboration with GE, boosted the firm's growth. However, there is no information on either the production volume of X-ray machines or the share of this division of total gross company sales until 1935, a year in which the value of X-ray appliances sold amounted to 1.7 million

22 Goto $1969,126$.

23 Siemens 1957, vol. 2, 79f. On this new technology, see Arns 1997.

24 Tokyo shibaura 1963, 474.

25 Goto 1969-1970.

26 Goto 1969, 148.

27 Shimadzu 1967, 45; Goto 1969, 179 quotes 1920.

28 Tokyo shibaura 1963, 708.

29 Shimadzu 1967, 378. 
yen, that is $19.2 \%$ of gross sales ${ }^{30}$. Supported by the Mitsubishi zaibatsu capital, Shimadzu was an enterprise that diversified extensively during the interwar period (machines, appliances, instruments, etc.), posting very high growth after its transformation into a joint stock company (1917) ${ }^{31}$. Its total gross sales rose from 2.8 million yen in 1920 to 8.9 million yen in 1935, while the number of employees went from 428 to 1318 persons over the same period $^{32}$. The firm's expansion was essentially driven by the domestic market and colonies, with the opening of sales subsidiaries at Dairen (1920), Seoul (1924) and Taipei (1931) ${ }^{33}$. The volume and nature of exports are not known, but Shimadzu did export some X-ray equipment to East Asia and Latin America during the interwar years ${ }^{34}$.

Thus, during the interwar period, Shimadzu succeeded in establishing itself alongside foreign multinationals as a key actor on the X-ray machine market. This was not only the result of particular conditions conducive to the firm's growth. Its success also stems from an expansion strategy that combined the internalisation of technological resources with an intense communication policy targeting medical circles.

\subsection{Shimadzu’s $R \& D$ policy}

In order to develop the production of X-ray machines that could compete with appliances imported from Germany and the United States, Shimadzu was obliged to internalise certain technological skills, a process essentially based on collaboration with external research centres, particularly Kyoto University. By hiring engineers who were graduates of technical colleges and universities and subcontracting some research activities to these centres, Shimadzu was able to benefit from advanced technologies that made it possible to develop new kinds of X-ray equipment. This internalisation of scientific and technical knowledge paid off in the early 1930s, when Tokyo Electric jumped into the production of complete X-ray devices.

Reliance on outside scientists was not merely a strategy of the X-ray machine division, but rather a general characteristic of the company. Indeed, Shimadzu recruited some scientists as consultants for various products in the

30 National Diet Library, Tokyo, Archives of the GHQ, USB-12, M1654-7, Interview with Shimadzu Manufacturing Co. Ltd, 26 October 1945.

31 Shimadzu 1967, 37.

32 Shimadzu 1967, annexes, 17-19 and 26. The exchange rate is 100 yen for about 50 US dollars in 1920 and 30 US dollars in 1934. Miwa/Hara (ed.) 2007, 115.

33 Shimadzu 1967, 57.

34 Shimadzu 1967, 44 and 76. 
1900s. In 1911, seven scientists worked together in this fashion, including one doctor $^{35}$. Five years later, in 1916, collaboration with another doctor, Hida Shichiro, made it possible for Shimadzu Genzo to obtain a first patent for an X-ray machine ${ }^{36}$. A graduate of the University of Tokyo (1898), Hida made a career as a surgeon in the army then as a private practitioner. He was one of the pioneers of radiology and of the use of X-ray machines in the practice of surgery in Japan ${ }^{37}$. What is more, he was among the 43 founders of the joint stock company Shimadzu Corporation in 1917.

In the 1920 s, Shimadzu beefed up its organisational R\&D capability by hiring engineers in charge of developing new X-ray devices. The first such engineer, Fukuda Shunichi, was a professor of physics at Kumamoto Industrial High School (Kumamoto koto kogyo gakko) when he was poached $(1920)^{38}$. Up until the time of his death in 1930, he supervised the set-up of new equipments, especially the launching in 1922 of the first radiotherapy machine built in Japan (Jupiter model) ${ }^{39}$, as well as a device designed for dentists (1928). Production volume was ramped up from some $100 \mathrm{X}$-ray machines in 1924 to 250 in $1926^{40}$. Yet despite this growth, Shimadzu relied on the outside for some special parts. For example, it did not produce any X-ray tubes, imported from the United States (GE) and Germany (Müller) ${ }^{41}$. However, the 1922 agreement signed with Tokyo Electric guaranteed a supply of Coolidge tubes ${ }^{42}$. In addition, Shimadzu depended on foreign firms for other specific parts. During his business trip to Europe in 1920, Shimadzu Tsunesaburo, brother to the president and member of the firm's board of directors, signed agreements with two producers of parts for X-ray equipment, CAF-Kahlbaum AG (Germany) for X-ray screens, and Gebrüder Miller $\mathrm{GmbH}$ (Austria) for X-ray spectrometers ${ }^{43}$. Under these conditions, it is possible that the subsidiary opened at Berlin in 1922, which remained operational until 1932, was tasked with obtaining some parts or technical assistance for the production of X-ray machines from German companies ${ }^{44}$. In particular, Shimadzu had business dealings with the multinational Siemens \& Halske, whose X-ray counters are imported to Japan at the end of the $1920 \mathrm{~s}^{45}$.

35 Shimadzu 1967, 27.

36 Database of the Industrial Property Digital Library, www.ipdl.inpit.go.jp/homepg.ipdl (accessed in February and March 2010).

37 Dainihon hakushi 1921-1930, vol. 2, 255-256; Goto 1970, 118.

38 Shimadzu 1967, 45.

39 Shimadzu 1967, 354.

40 Shimadzu 1967, 356.

41 Shimadzu 1967,378.

42 Shimadzu 1967, 45.

43 Shimadzu 1967, 47.

44 Shimadzu 1967, 48.

45 Goto 1969, 22. 


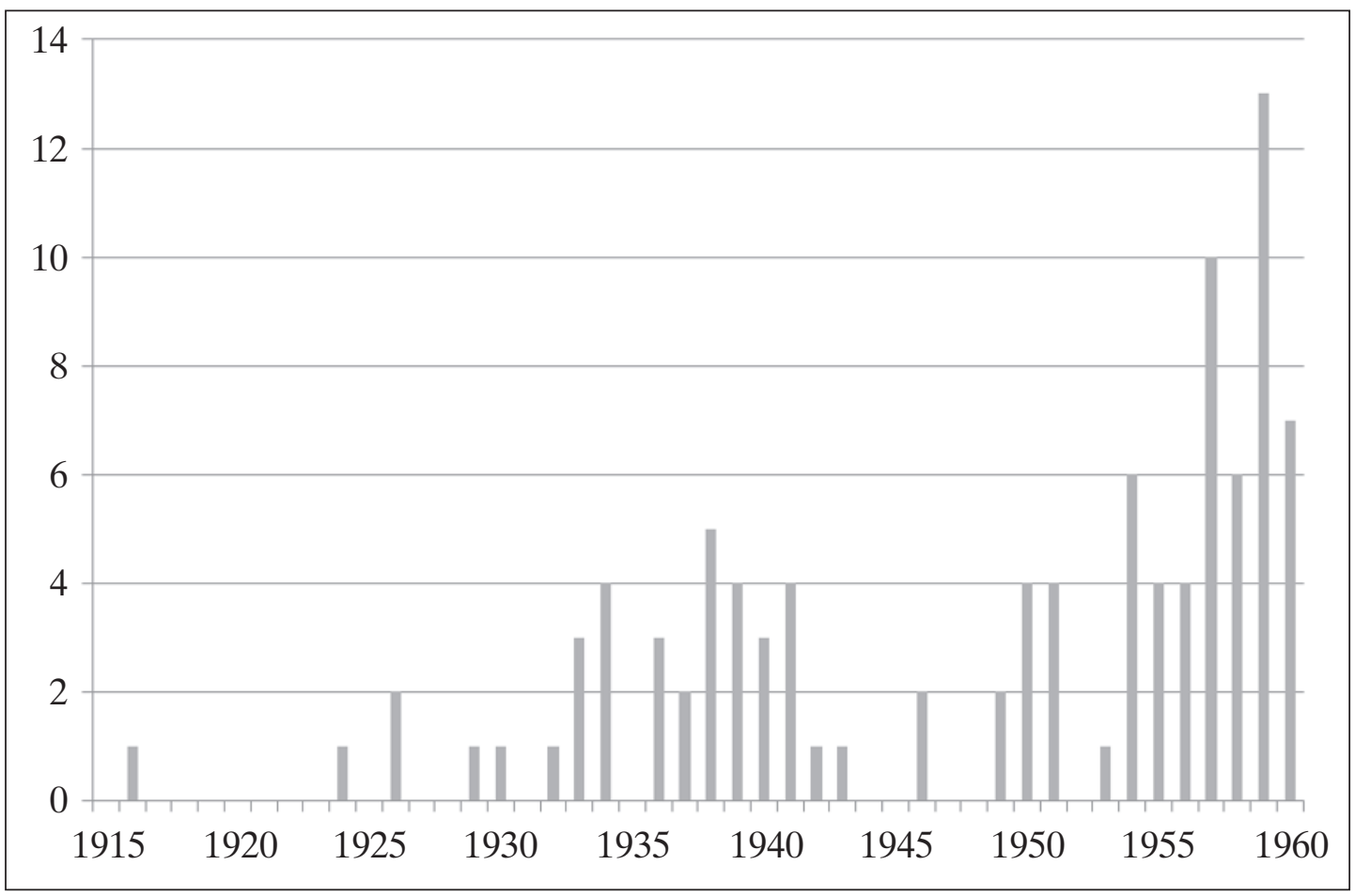

Fig. 1. Patents of Shimadzu Co registered in the field of radiology, 1916-1960. This figure covers the patents registered by Shimadzu Genzo (1), Shimadzu Corporation (98) and its subsidiary Japan Quartz Industry (1). Source: Database of the Industrial Property Digital Library, www.ipdl.inpit.go.jp/homepg.ipdl (accessed in February and March 2010) and Tokkyo bunrui 1958.

Thus, until 1930 Shimadzu was an assembler of X-ray equipments, highly developed of course, but dependent on the outside for technology. What is more, the company obtained only four patents in the field of radiology during the $1920 \mathrm{~s}$, that is, $7.0 \%$ of the total amount of patents registered in Japan in this field ${ }^{46}$.

In the early 1930s, the market became very competitive when Tokyo Electric embarked upon the production of complete X-ray machines and Siemens embarked upon a joint venture to manufacture them in Japan (Goto Fuundo Manufacturing Co, 1933) ${ }^{47}$. Shimadzu reacted by strengthening its organisational capabilities. After the death of Fukuda in 1930, the management of the $\mathrm{X}$-ray machine division was entrusted to a graduate of the Faculty of Sciences of Tohoku University, Sekito Kikuchi ${ }^{48}$. After completing his studies, he

46 Database of the Industrial Property Digital Library, www.ipdl.inpit.go.jp/homepg.ipdl (accessed in February and March 2010) and Tokkyo bunrui 1958.

47 Siemens Archives, Erlangen (Germany), Agreement between S. Goto Fuundo Ltd, Tokyo, and Siemens-Reiniger-Werke AG, Berlin, 30 June 1932-25 November 1933, not marked. 48 Matsushita 1940, vol. 6, 229f. 
taught in a technical college at Hamamatsu before returning to Tohoku University, where he worked as a researcher and obtained his $\mathrm{PhD}$ in $1930^{49}$. Other engineers were engaged to work under Kikuchi, among whom was Nakabori Kouji ${ }^{50}$. After graduating from the Department of Electrical Engineering at the Faculty of Engineering of Kyoto University in 1935, he entered Shimadzu immediately thereafter, where he spent his entire career as a researcher, obtaining his $\mathrm{PhD}$ at Kyoto University in 1956 and becoming a member of the board of directors in $1963^{51}$.

In addition to this strategy of employing engineers with university degrees, in the early 1930s Shimadzu cooperated with outside institutions with regard to R\&D on Coolidge tubes ${ }^{52}$. In 1932, it commissioned the Aoyagi Research Laboratory, which was headed by a professor of Kyoto University specialised in research on vacuum tubes, to do research for it ${ }^{53}$. That same year, Shimadzu also subcontracted some R\&D to an Osaka-based firm in which it invested, the Japan Quartz Industry Co (Nihon sekiei kogyo). In 1934, this company produced a prototype of a Coolidge tube, based on a model from the German company Müller, which it delivered to Shimadzu ${ }^{54}$. Subsequently, Shimadzu began in-house production of these tubes in $1940^{55}$.

As a result of Shimadzu's technological development in the first part of the 1930s, the firm obtained a growing number of patents: it registered 23 during this decade, that is, $21.7 \%$ of all the patents registered in Japan during that period for X-ray equipment. Shimadzu became one of the main players in this new industry. As for the products marketed, Shimadzu appears to have been very active here as well, launching 19 new appliances during the $1930 \mathrm{~s}^{56}$.

\subsection{Making its machines known}

Together with the development of its technological competences, Shimadzu did adopt in the interwar period an active strategy of supporting the dissemination of its X-ray machines within the medical world. This strategy was

49 Goto 1970, 114.

50 Goto $1970,312$.

51 Yamada 2005, 2.

52 Shimadzu 1967, 79.

53 Dainihon hakushi 1921-1930, vol. 5, 108f.

54 Shimadzu 1967,378. In fact, the tubes of the firm Müller were made at that time by the Dutch company Philips, to which Müller belonged since 1927. Kees 2003, 82.

55 Shimadzu 1967, 80.

56 Shimadzu 1967, 79. 
at the crossroads of scientific communication related to the utilisation and usefulness of X-ray machines and a pure advertisement for its own products. The dual dimension of this strategy can be explained by the fact that X-ray equipment was new and it was necessary to explain its proper use, on the one hand, and because the market was extremely competitive, with the presence of multinational firms such as Siemens and GE, on the other hand. The objective of this policy was thus twofold: encouraging the consumption of $\mathrm{X}$-ray equipment, and if possible Shimadzu-made material.

The early communication policy was initially consistent with a company producing scientific instruments for education, that is, Shimadzu's traditional market. Until 1908, the X-ray machines made by Shimadzu were destined for schools rather than doctors. Siemens' quasi-monopolistic domination of this market in Japan doubtless delayed Shimadzu's diversification into a new market, the medical sector. For some ten years, Shimadzu viewed its X-ray machines as scientific instruments suited to physics classes. Thus, soon after producing the first X-ray equipment for teaching (1897), Shimadzu Genzo made public presentations at conferences in the Kansai region (Kyoto, Osaka, Kobe $)^{57}$. In 1908, at a Kyoto nationwide meeting of secondary school directors, he demonstrated the working of his appliances ${ }^{58}$. After World War I, when his X-ray machines became instruments designed for medical practice, Shimadzu pursued and developed this communication policy, which consisted of three main thrusts: establishing networks in the medical world, organising scientific events and setting up schools for radiology technicians.

First of all, Shimadzu established ties with medical circles through doctors. This approach appears as a key element of the expansion strategy towards the medical field adopted by the company in the 1910s. When Shimadzu was turned into a joint stock company in 1917, Shimadzu Genzo comprised 42 persons, of whom 12 were doctors (see table 1). This proximity between doctors and engineers may bring to mind collaboration aimed at the development of new medical devices, as could be seen in Europe in the 1950s and $1960 \mathrm{~s}^{59}$. In the case of Shimadzu, however, the relationship with doctors was different. Their presence cannot be explained by a desire to work together to develop X-ray machines. Except for the surgeon Hida Shijiro, the idea man behind the first X-ray device for medical practice produced by Shimadzu (1915) and co-founder of the Tokyo-based firm Hida Electric Industry $(1915)^{60}$, none of these doctors were engaged in the development of

57 Goto 1969, 18.

58 Goto 1969, 64.

59 Schlich 2002; Anderson/Neary/Pickstone, 2007.

60 It produced notably some X-ray tubes. Goto 1969, 127. 
Tab. 1. Founding doctors of Shimadzu Corporation Ltd, $1917^{1}$.

\begin{tabular}{ll}
\hline Name & Career \\
\hline $\begin{array}{l}\text { Hida Shichiro } \\
(1872-?)\end{array}$ & Army career as a surgeon; director of Hida Hospital, Tokyo (circa 1910) \\
\hline $\begin{array}{l}\text { Kitagawa Otojiro } \\
(1864-1922)\end{array}$ & $\begin{array}{l}\text { Director of Wakayama Prefectural Hospital (1890); director of } \\
\text { Koseikwan Hospital, Nagoya (1891); President of the Medical Society } \\
\text { of Nagoya }\end{array}$ \\
\hline $\begin{array}{l}\text { Kusunoki Futo } \\
(1876-?)\end{array}$ & $\begin{array}{l}\text { Professor at Aichi Medical College, Nagoya (1912); private practice } \\
\text { at Nagoya (1916). }\end{array}$ \\
\hline $\begin{array}{l}\text { Nakahara Tokutaro } \\
(1871-1926)\end{array}$ & $\begin{array}{l}\text { Vice-director of Rakusando Hospital, Tokyo (1900); director of } \\
\text { Nakahara Hospital, Tokyo (1912); director of Nippon Medical College, }\end{array}$ \\
\hline $\begin{array}{l}\text { Nakarai Nao } \\
\text { Nanba Kaname } \\
(1873-1929)\end{array}$ & $\begin{array}{l}\text { Unknown } \\
\text { Director of Nogeyama Hospital, Yokohama (1903), and then of Nanba }\end{array}$ \\
$\begin{array}{l}\text { Ogata Masakayo } \\
(1864-1919)\end{array}$ & $\begin{array}{l}\text { Director of the Ogata Obstetrical-Gynaecological Hospital, } \\
\text { Osaka (1893); member of the Osaka Municipal Assembly }\end{array}$ \\
\hline
\end{tabular}

Sakura Tsunesaburo Army career as a surgeon; director of Daikan Hospital, in Korea. (1855-1921)

\begin{tabular}{ll}
\hline $\begin{array}{l}\text { Sato Kinya } \\
(1864-1920)\end{array}$ & Vice-director of Koseikwan Hospital, Nagoya (1891) \\
\hline Shibata Koichi & Unknown \\
\hline Takeda Kunimatsu & Unknown \\
\hline $\begin{array}{l}\text { Takayasu Michishige } \\
(1872-?)\end{array}$ & $\begin{array}{l}\text { Director of Takayasu Hospital, Osaka (circa 1899); director of the } \\
\text { Osaka Charity Hospital; President of the Physicians' Association } \\
\text { of Osaka. }\end{array}$ \\
\hline
\end{tabular}

1 Shimadzu 1967, 36. Source: Dainihon hakushi 1921-1930, vol. 2-4 and the database http:// kotobank.jp/ (accessed in March 2010).

radiology and medical devices. For example, no one, not even Hida, held any patents in the field of radiology ${ }^{61}$. More than a source of know-how, these doctors were a key resource for the commercial opportunities of the firm. The nine doctors which career is known have similar profiles. They were all part of the "nameless practitioners" who transformed the Japanese medical system during the Meiji period ${ }^{62}$. Alongside the great medical figures of the Universities of Tokyo and Kyoto who captured the interest of scholars, there was also a specific medical elite who stayed in the shadow of historiography

61 Database of the Industrial Property Digital Library, www.ipdl.inpit.go.jp/homepg.ipdl (accessed in February and March 2010).

62 Donzé 2010. 
but played a key role in the modernisation of Japanese medicine: private practitioners trained abroad on their own. A stay in a Western university, essentially in German-speaking countries, was not integrated into an academic career but viewed as a long-term investment. On a very competitive Japanese hospital market - there were 808 hospitals in 1910, of which $88.9 \%$ were private $^{63}$ - German training conferred an edge, as only a small minority of doctors benefited from this kind of background ${ }^{64}$.

The doctors who helped turned Shimadzu into a joint stock company in 1917 all belonged to this group of "nameless practitioners". They enjoyed excellent training: apart from Sakura, all held doctoral degrees from the University of Tokyo or the University of Kyoto, that is, the best medical schools in the country. What is more, seven of them trained in Europe, mainly in German and Austrian faculties. These training trips were carried out at their own expense, i.e. as long-term investments, except for Kusunoki and Sakura. In 1917, when Shimadzu Corporation Ltd was founded, they were running private hospitals they owned, in addition to which several were engaged in professional associations. The career of Ogata Masakyo perfectly exemplifies these various aspects. Born in 1864, himself the son of a doctor, he studied medicine at the University of Tokyo before training at his own expense in Germany and Austria, where he specialised in gynaecologyobstetrics (1888-1892). Upon his return to Japan, he joined the hospital founded by his father at Osaka, where he took over the management. Obtaining his $\mathrm{PhD}$ in medicine from the University of Tokyo in 1905, he was a notable of Osaka in the early 20th century. President of the Osaka Physicians' Association and of the Osaka Midwifery Association, as well as VicePresident of the Dai-Nihon Physicians' Association, he also served as Director of the Osaka Charity Hospital's College of Medicine and was a member of the Osaka Municipal Assembly. Finally, he ran a medical laboratory in the city of Osak ${ }^{65}$. Like him, the doctors who joined Shimadzu were entrepreneurs who helped turn medicine into a business. For these private practitioners, new technologies such as X-ray machines were destined to not only improve their medical practice but also strengthen their position on the medical market. This was probably their main interest when they came on board in 1917. As for the firm itself, the purpose of this collaboration with such doctors was obvious: it allowed the company to access networks facilitating the sale and distribution of new devices, which were then launched on the market.

63 Nihon choki 2006, vol. 5, 170f.

64 Donzé 2010.

65 Dainihon hakushi 1921-1930, vol. 2,78f. 
Shimadzu's involvement in the medical world was not limited to welcoming doctors among its shareholders. It also developed an active communication policy, primarily geared to organising and participating in scientific events. For example, in 1921 Shimadzu ran a one-week course (koshukai) introducing the principles of X-ray machines and their possible applications to medicine. The aim was to present new models to doctors and their assistants and to explain their proper use. Organised each year, this course became increasingly popular, with 22 participants in 1921, 80 in 1922 and 113 in $1924^{66}$. It was subsequently taken over and pursued in 1940 by the Japanese Medical Radiology Society (Nihon igaku hoshasen gakkai) ${ }^{67}$.

Tab. 2. Content of the first one-week course, June $1921^{1}$.

\begin{tabular}{ll}
\hline Lecturer & Title \\
\hline $\begin{array}{l}\text { Mori Sonosuke, professor of physics at Kyoto } \\
\text { Third High School }\end{array}$ & $\begin{array}{l}\text { On the nature of radiological tubes and } \\
\text { X-rays }\end{array}$ \\
\cline { 2 - 2 } $\begin{array}{l}\text { On the techniques to become proficient } \\
\text { at taking X-ray pictures }\end{array}$ \\
\hline $\begin{array}{ll}\text { Urano Tamonji, doctor, head of the radiology } \\
\text { department of the Osaka Kaisei Hospital, } \\
\text { lecturer at Kyoto University }\end{array}$ & $\begin{array}{l}\text { On the application of the techniques } \\
\text { to make a X-ray diagnosis for specific } \\
\text { affections }\end{array}$ \\
\cline { 2 - 2 } & $\begin{array}{l}\text { On the application of the techniques to } \\
\text { conduct X-ray therapy for specific affections }\end{array}$ \\
\hline $\begin{array}{l}\text { Fukuda Shunichi, physician, Shimadzu Co } \\
\text { Aoyagi Eiji, professor of electrical } \\
\text { engineering at Kyoto University }\end{array}$ & $\begin{array}{l}\text { The concept of electricity and the principle } \\
\text { of the X-ray machine }\end{array}$ \\
\hline $\begin{array}{l}\text { Ishino Matayoshi, professor of physics } \\
\text { at Kyoto University }\end{array}$ & Belief and science \\
\hline $\begin{array}{l}\text { Matsuo Iwao, professor of medicine } \\
\text { at Kyoto University }\end{array}$ & On the structure of material and X-ray \\
\hline $\begin{array}{l}\text { Hayashi Nobuo, doctor, private practice } \\
\text { at Nagoya and Chiba prefecture }\end{array}$ & Internal medicine looked at by X-rays \\
\hline $\begin{array}{l}\text { Tanaka Kazuhiko, radiologist at Osaka } \\
\text { University Hospital }\end{array}$ & Photographs (practical lesson) \\
\hline $\begin{array}{l}\text { 1 Goto 1969, 191f. Source for biographies: Dainihon hakushi 1921-1930, vol. 2-4 and the data- } \\
\text { base http://kotobank.jp/ (accessed in March 2010). }\end{array}$ & \\
\hline
\end{tabular}

66 Shimadzu 1967, 49. The numbers are unknown for the following years. In 1923, a similar course for dentists was organised.

67 Shimadzu 1967, 49. 
The content of the first one-week course organised in 1921 once again shed light on the collaboration between Shimadzu, Kyoto University, and some private practitioners. Besides Fukuda, the head of the X-ray machine division at Shimadzu, there were indeed three professors from Kyoto University and one from Kyoto Third High School, together with three practitioners, including Urano, who left Kansei Hospital in 1933 to open one of the first private radiology institutes of Japan ${ }^{68}$. Yet organising such courses was not an original idea hatched by Shimadzu. Indeed, doctors involved in the beginnings of radiology staged similar demonstration courses in some hospitals and faculties of medicine starting in the early 1910s. As for X-ray machines manufacturers and sellers, Goto Fuundo, a Tokyo-based competitor of Shimadzu that imported German X-ray machines into Japan, first organised such a course in 1908 at a meeting of the Japanese Association of Digestive Organ Diseases (Nihon shokakibyo gakkai) ${ }^{69}$. In 1918, the X-ray tube maker Tokyo Electric also ran a similar course. Like Shimadzu three years later, the lectures were given by the engineers of the firm as well as some professors of medicine. They aimed at passing on theoretical knowledge on the physical principles of radiology and also on their medical applications using the firm's products ${ }^{70}$.

In addition to this one-week course, Shimadzu actively engaged in the scientific life of medicine from the mid-1920s onwards, mainly through the engineer Fukuda, who participated in the activities of the Japanese Roentgen Association, presenting papers at annual conferences and publishing articles in the society's journal ${ }^{71}$. Shimadzu itself organised some scientific events. In February 1924, to mark the first anniversary of Wilhelm Roentgen's death, the enterprise set up a Roentgen Festival (rentogensai), gathering together in Kyoto more than 200 persons who heard a series of scientific communications $^{72}$. A similar event has taken place since then every year, a practice which still exists today. Moreover, Shimadzu has also published since 1925 its own scientific journal, the Shimadzu Radiology Bulletin (Shimadzu rentogen jiho), which largely consists of articles by the firm's employees ${ }^{73}$.

Finally, the last communication strategy adopted by Shimadzu during the interwar period was to set up a training centre for radiology technicians. While contributing to the professionalisation of the assistants in charge of

68 Goto 1970, 230.

69 Goto 1969, 64.

70 Goto 1969,159 f.

71 Goto 1969-1970.

72 Shimadzu 1967, 50.

73 It was renamed Shimadzu Hyoron (1940) and still exists today. See www.shimadzu.co.jp/ tec_news/index.html (website accessed 19 March 2010). 
X-ray machines in hospitals and clinics, the firm not only ensured the training of a new generation of technicians able to use X-ray equipment effectively but also backed the diffusion of this new technology into Japanese healthcare institutions and encouraged the use of its own apparatuses ${ }^{74}$. After World War I, Japanese universities gradually organised specific training for radiologists (doctors), as embodied by the successive opening of radiology departments at Keio University (1919), Osaka Medical College (1925, Osaka University since 1931) and Kyoto Prefectural University of Medicine $(1928)^{75}$. Nonetheless, the training of these doctors' assistants was not covered by any institution, and Shimadzu played a key role in this process of professionalisation.

Tab. 3. Lecturers at the Kyoto Training Center for X-Ray Technology, $1927^{1}$.

\begin{tabular}{ll}
\hline Name & Career \\
\hline $\begin{array}{l}\text { Fukuda Shunichi, } \\
\text { director }\end{array}$ & Engineer at Shimadzu; head of R\&D on X-ray devices \\
\hline Aoyagi Eiji & $\begin{array}{l}\text { Professor of electrical engineering at Kyoto University; } \\
\text { founder of the private R\&D centre Aoyagi }\end{array}$ \\
\hline Urano Tamonji & $\begin{array}{l}\text { Doctor; head of the radiology department at Kansei Hospital, } \\
\text { Osaka; lecturer at Kyoto University; shareholder in Shimadzu Co }\end{array}$ \\
\hline Saito Taiga & $\begin{array}{l}\text { Doctor; President of the Japanese Roentgen Society } \\
\text { (Nihon rentogen gakkai); shareholder at Shimadzu Co }\end{array}$ \\
\hline Kurimoto Shuroku & Engineer at Shimadzu \\
\hline \begin{tabular}{l} 
Nagasaka Kamesaburo \\
\hline Ueyama Masahide
\end{tabular} & Engineer at Shimadzu \\
\hline $\begin{array}{l}\text { Fujimoto Keiji } \\
\text { Engineer at Shimadzu }\end{array}$ \\
$\begin{array}{l}\text { Goto 1970, 28. Source for biographies: Dainihon hakushi 1921-1930, vol. 2-4; the data- } \\
\text { base http://kotobank.jp/ (accessed in March 2010); and Shimadzu Corporation, Eigyo } \\
\text { hokokusho, 1929-1930, list of shareholders. }\end{array}$
\end{tabular}

The Training Centre for X-Ray Technology (Rentogen gijutsu koshujo) was opened at Kyoto, close to the Shimadzu factory, in 1927. Once again, the composition of the teaching staff reflected Shimadzu's close cooperation ties with universities and private practitioners (see table 3). The center, run by Fukuda, also employed four other engineers. As for the three external lecturers, they were Professor Aoyagi and Doctor Urano, both of whom also

74 The professionalization of X-ray technicians was not solely due to a process of defining common working methods and cognitive referents by workers themselves, as emphasized by Pasveer 1989.

75 Shimadzu 1967, 59. 
attended the one-week course organised in 1921, as well as another doctor, Saito Taiga, President of the Japanese Roentgen Society (Nihon rentogen gakkai) ${ }^{76}$. The centre was open to students who graduated from a junior high school. The course lasted six months, and was subsequently extended to nine months in 1933 and twelve months in 1936. The first year, 40 students entered the school, of whom half were sent by public institutions (army, navy, national railways, etc. $)^{77}$. Renamed the Special School for X-Ray Technology (Rentogen gijutsu senshu gakko) in 1935, this centre remained a pioneer until the 1950s, playing a key role in the training of X-ray technicians in Japan until then. Together with the Osaka School of Physiotherapy, which was founded in 1935 and ran courses for X-ray technicians from 1935 onwards, it was the only training centre for these technicians until 1950. In 1951, the enforcement of a new law on the training of employees in charge of radiology made it compulsory to hold an official degree for such a position. This led to the creation of new schools, usually within faculties of medicine and university hospitals ${ }^{78}$, as a result of which the number of schools for X-ray technicians rose from two in 1950 to 16 in $1960^{79}$. However, the impact of this law was not only the appearance of rival schools, but also a growing number of students for the Special School for X-Ray Technology backed by Shimadzu: the average number of graduates increased from 25 in 1935-1939 to 52 in 1955-195980.

\subsection{Producing during the war}

After the war against China began in 1937, Shimadzu was, like other Japanese enterprises, instructed to shift to producing war material. However, even if the relative importance of the X-ray machine division declined during the war $(19.2 \%$ of gross sales in $1935 ; 17.8 \%$ in $1940 ; 8.8 \%$ in 1944$)$, the production volume continued to increase, with its value rising from 1.7 million yens in 1935 to 4.7 million in 1940 and 6.2 million in $1944^{81}$.

The army was Shimadzu's main customer. It mass-ordered X-ray appliances for its medical support teams servicing its troops and its hospitals ${ }^{82}$. This specific demand for simple, light and easily transportable devices also spurred R\&D within the firm. A total of 20 new patents were registered for the years

76 Goto 1970, 28.

77 Shimadzu 1967, 59.

78 Isei 1976, 601f.

7935 nen $1984,264 f$.

80 Toseki, 1977, 166.

81 National Diet Library, Tokyo, Archives of the GHQ, USB-12, M1654-7, Interview with Shimadzu Manufacturing Co. Ltd, 26 October 1945. The exchange rate of 100 yen was about 30 US dollars in 1934. Miwa/Hara (ed.) 2007,115.

82 Shimadzu 1967, 86. 
$1937-1943$ (19.0\% of the total). In particular, Shimadzu rolled out an indirect radiography machine in 1938, adopted two years later by the army for the enrolment of soldiers. This context also explains the development of an $\mathrm{X}$-ray automobile machine for collective radiographies ${ }^{83}$. Furthermore, these new machines were to provide an essential base on which Shimadzu founded its growth in the 1950s.

\section{A new period of growth (1945-1960)}

Immediately after the end of the war, the question of the production of $\mathrm{X}$-ray machines became a key issue in terms of public health policy. The deterioration of living conditions during the war was said to have facilitated the spread of tuberculosis throughout the country, and the new Japanese authorities made the fight against tuberculosis a major political concern ${ }^{84}$. Moreover, the hospitals and local health centres destroyed during the war had to be equipped once again. Accordingly, domestic production of X-ray machines increased steadily, rising from 2794 machines in 1947 to 7511 in $1960^{85}$. In 1953, the first national census of medical equipments showed that $86.8 \%$ of hospitals (health institutions with more than 20 beds) and $38.2 \%$ of clinics (health institutions with 19 beds or less) had X-ray machines ${ }^{86}$. These proportions amounted to $90.1 \%$ and $56.6 \%$ respectively in $1960^{87}$. At the time, the medical market was characterised by high growth and keen competition: Shimadzu still faced its rivals, Tokyo Electric (Tokyo Shibaura Electric since 1939 and Toshiba since 1979) and Siemens, in addition to a newcomer Hitachi entered this fast-growing sector in 1951 by acquiring a small-scale manufacturer active since the 1920s, Shibuya Works ${ }^{88}$.

Shimadzu experienced a high-growth phase starting in the late 1940s. The years 1946-1949 were a period of revival. In May 1946, Shimadzu obtained authorisation to once again produce some devices and machines, including $\mathrm{X}$-ray appliances with an authorised monthly production of 30 devices, subsequently raised to 59 in January 1949) then to 68 in January $1950^{89}$. In addition, it exported some equipment and parts to Korea, where its machines

83 Shimadzu 1967, 78f.

84 Aoki 2004.

85 Kikai tokei nenpo, Tokyo: Ministry of International Trade and Industry, various volumes.

86 This statistical definition was adopted at first by the Health Bureau of the Ministry of Interior in 1933, with the limit fixed at 10 beds, and raised to 20 beds in 1948. Sugaya 1981, 9f.

87 Ministry of Health, 1953-1960.

88 There was the company Shibuya Roentgen Co. Hitachi 1960, vol. 2, $358 f$.

89 National Diet Library, Tokyo, Archives of the GHQ, CAS (C)-06153-54, permit No. 107 ok-283, 31 May 1946 and ESS (b)-14843-44, General information on Shimadzu Seisakujo, 31 March 1950, p. 4. 
had been sold in great quantities until the war ${ }^{90}$. These sales made it possible to restart production in the Kyoto factory after the war, but growth was primarily driven by domestic demand after 1950 . Sales of X-ray equipment by Shimadzu soared from 222 million yen in 1949 to 1.2 billion yen in 1960, enabling Shimadzu to remain among the leading Japanese producers of X-ray machines. It had an average market share of $44.5 \%$ for $1954-1960$ (see fig. 2).

As was the case before the war, this development was based on the model of the internalisation of external capabilities and an active R\&D policy. Cooperation ties with Kyoto University and university researchers continued during and after the war. Thus, Kato Noboyoshi, a professor of electrical engineering at Kyoto University, was engaged as a consultant in $1944^{91}$. More-

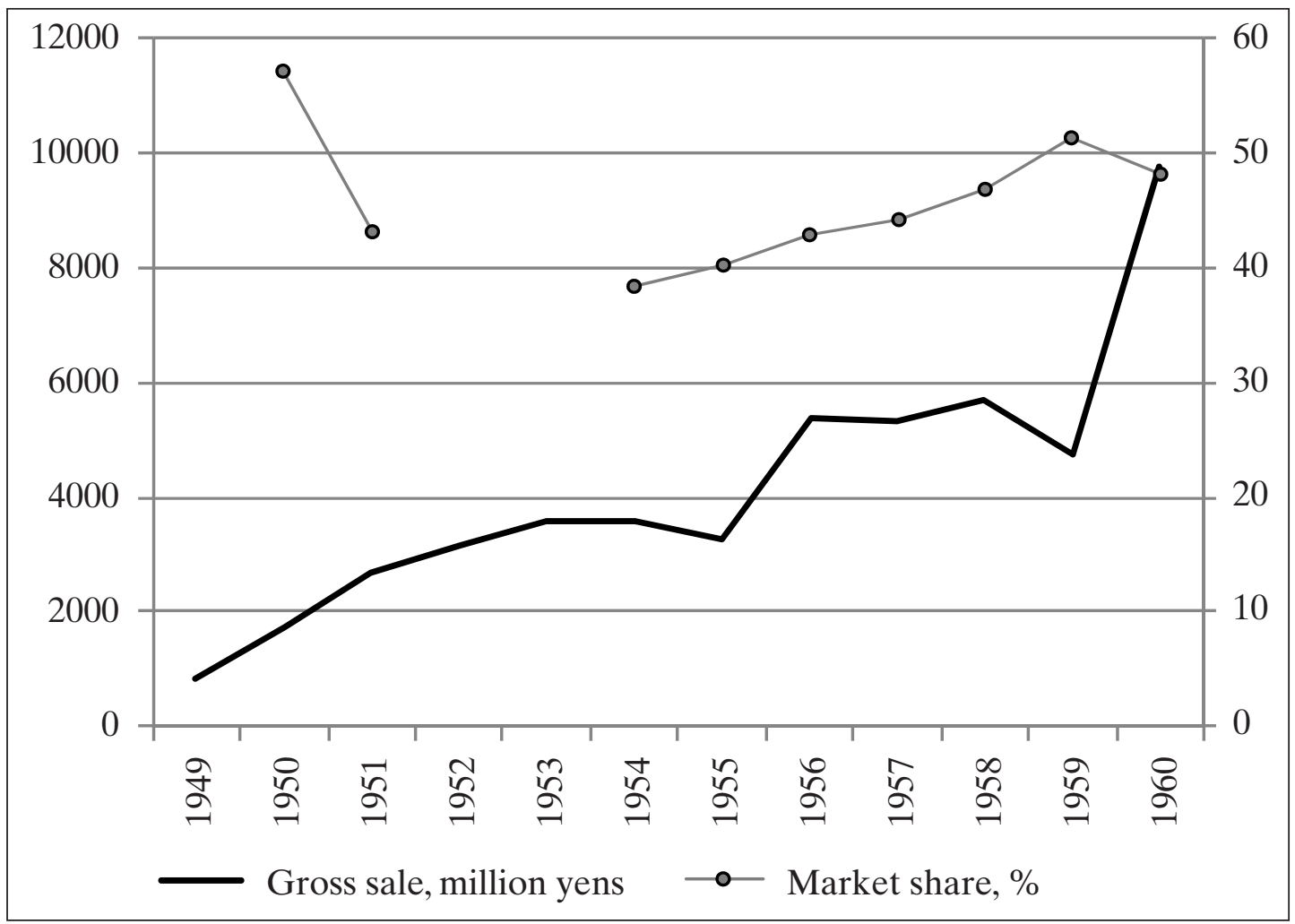

Fig. 2. Gross sales of the X-ray division and market share of Shimadzu, 1949-1960. Sources: Kaisha nenkan, Tokyo: Nihon keizai shimbun, 1951-1963 and Kikai tokei nenpo, Tokyo: Ministry of International Trade and Industry, 1950-1961. The value of the national production of X-ray machines was unknown in 1953 and 1954. Between 1949 and 1970, the yen had a fixed parity with the US dollar (1 US dollar = 360 yen).

90 The number of X-ray devices in Korea was estimated at 820 in 1947, of which some 70\% was thought to be of Japanese origin. National Diet Library, Tokyo, Archives of the GHQ, ESS (B)-04535, Import requirements to Korea, 1 July 1946 to 31 May 1947. On Shimadzu in Korea, see also GHQ, ESS (B)-04535, memorandum from the Chief of the Machinery and Metal Section to the Chief of the Minerals and Chemicals Branch, 9 May 1949.

91 Shimadzu 1967, 379. 
over, between 1946 and 1960, four Shimadzu researchers earned PhDs, three from Kyoto University and one from Jikei University, for research on X-ray technology ${ }^{92}$. Finally, Shimadzu benefited from public support for R\&D. Six research projects were funded by the Ministry of Education in 1949-1950, followed by two others by the Ministry of International Trade and Industry (MITI) in 1954-195593.After the war, an engineer hired around the mid-1920s, Fujimoto Keiji, became director of the X-ray division. He was a scientist actively engaged in the Japanese Roentgen Association ${ }^{94}$, and taught in the early 1940s at the Faculty of Medicine of Kokkaido University ${ }^{95}$.

Parallel to the pursuit of collaboration with academic research, Shimadzu adopted a second technological development strategy: cooperation with a foreign multinational company. The firm's integration into the Mitsubishi group led to its inclusion in the negotiations on a general technology cooperation agreement signed in 1951 with the American firm Westinghouse Electric Co., which had been working together with Mitsubishi Electric since $1923^{96}$. The 1951 agreement enabled Shimadzu to benefit from the technologies of the American company and stay competitive with its rivals on the Japanese market.

These various cooperation arrangements enabled Shimadzu to pursue an active innovation policy, as revealed by patent statistics: the company registered a total amount of 52 patents for $1950-1959$ - that is, $15.8 \%$ of the total - to which can be added the 17 patents registered at the time by Westinghouse $(5.2 \%)^{97}$. From 1945 to 1960 , Shimadzu rolled out more than twenty new appliances, notably some intended for screening for tuberculosis and cancer, which were mass-ordered by the Ministry of Health ${ }^{98}$.

\section{Conclusion}

The diffusion of new medical technologies in Japan during the first part of the 20th century, approached through the example of X-ray machines produced by Shimadzu, underscores the key influence of the market structure in this process, in this case a competitive and relatively liberalised market.

92 Three at Kyoto University and one at Jikei University. Shimadzu 1967, 453.

93 Shimadzu 1967, 451f.

94 See for example Goto 1970, 379.

95 Ika kikai gaku zasshi 17/7 (1940) 171.

96 Yamazaki 2004,169-197. Moreover, Mitsubishi Heavy Industry was in 1950 the second biggest shareholder of Shimadzu (3.8\% of the capital) behind the director Shimadzu Genzo. Kaisha nenkan, Tokyo: Nihon keizai shimbun, 1952.

97 Database of the Industrial Property Digital Library, www.ipdl.inpit.go.jp/homepg.ipdl (accessed in February and March 2010) and Tokkyo bunrui 1958.

98 Shimadzu 1967, 368f. 
Western historiography usually tends to stress the importance of social networks, especially doctors' ones, in a social construction of technology (SCOT) approach, and this of policy control by the State, to explain the diffusion of medical technologies ${ }^{99}$. The rare analyses that incorporate the economic dimension are about regulated markets, in which the State plays a decisive role in terms of technical equipment, as can be observed for example in the cases of osteosynthesis and dialysis devices after World War $\mathrm{II}^{100}$. Thus, up to that point, the attention was focused on the users and consumers of technologies (State, doctors, hospitals and patients) rather than on their producers, that is the medical device manufacturers, as if they had played only a passive role in the diffusion of technologies ${ }^{101}$. This paper has adopted a complementary approach - namely that of business history.

The diffusion of radiology in Japan occurred in a particular economic context, that of a fast-growing, largely privatised and competitive hospital market. This market structure had two main impacts on the firm's management. First, it led Shimadzu to adopt very early on a strategy of insertion into the medical networks, with the collaboration of private doctors, involvement in scientific activities, and the creation of a training school for X-ray technicians. Second, owing to its fast growth and keen competition, the medical market required a technological development strategy based on the internalisation of capabilities from universities, especially Kyoto University, and external R\&D centres. Finally, on both sides, access to domestic external resources, such as medical networks and technological know-how developed within universities, enabled Shimadzu to establish itself as the first Japanese producer of X-ray machines and to compete effectively with American and German multinational enterprises. Viewed from this perspective, the structure of the Japanese medical market had a positive impact on the diffusion of new technologies and the growth of a domestic medical device industry. It is difficult to make a comparison with other medical devices due to a lack of research in this field, but a quick glance at the Japanese foreign trade statistic shows that the interwar years were also as a pivotal period for the surgical instrument industry. After posted steady growth in the years following World War I, peaking at 1.1 million yen in 1924, imports indeed entered a phase of continuous decline, due to the development of national production. Exports even overtook imports in $1928^{102}$.

99 See for example Arns 1997; Stanton 2002; Anderson/Neary/Pickstone 2007.

100 Battista 1989; Schlich 2002; Stanton 2002b.

101 Gelijns/Rosenberg 1994.

102 Ministry of Finance 1907-1939. 
A complete business history approach would also require due consideration of the perspective of customers - hospitals, clinics - in order to analyse the impact of new technologies on the management of these institutions, the evolution of the medical market structure and the diffusion of technologies towards patients. The liberalised and atomised structure of the Japanese medical market led to keen competition between healthcare institutions which obviously favoured the diffusion of new technologies that could have been used as distinguishing features and comparative advantages. Indeed, the Japanese hospital system is made of numerous, mainly private and small health centres. In 1960, there were a total of 6,094 hospitals (byoin) - of which $74.2 \%$ were private - with 113 beds on average, together with 59,008 clinics (shinryojo) - nearly all private - with 3 beds on average ${ }^{103}$. At the time, $90.1 \%$ of hospitals and $56.6 \%$ of clinics were equipped with X-ray installations ${ }^{104}$. Under these conditions, hospitals and especially clinics probably made frenzied use of these devices to ensure their amortisation, which would largely explain why Japan is even today the country with the highest density of medical imaging devices in the world ${ }^{105}$.

\section{Bibliography}

Anderson, Julie/Francis Neary/John V. Pickstone, Surgeons, Manufacturers and Patients: A Transatlantic History of Total Hip Replacement (Basingstoke 2007)

Aoki, Junichi, Kekkaku no shakaishi (Tokyo 2004)

Arns, Robert G., "The High-Vacuum X-Ray Tube: Technological Change in Social Context", Technology and Culture 38 (1997) 852-890

Battista, Renaldo N., "Innovation and diffusion of health-related technologies", International Journal of Technology Assessment in Health Care 5 (1989) 227-248

Blume, Stuart S., Insight and Industry. On the Dynamics of Technological Change in Medicine (London/Cambridge 1992)

Dainihon hakushi roku (Tokyo 1921-1930)

Donzé, Pierre-Yves, «Les systèmes hospitaliers contemporains, entre histoire sociale des techniques et business history», Gesnerus. Swiss Journal of the History of Medicine and Sciences 62 (2005) 273-287

Donzé, Pierre-Yves, L’ombre de César. Les chirurgiens et la construction du système hospitalier vaudois (1840-1960) (Lausanne 2007)

Donzé, Pierre-Yves, "Studies Abroad by Japanese Doctors: A Prosopographic Analysis of the Nameless Practitioners, 1862-1912", Social history of medicine 23/2 (2010) 244-260

Gelijns, Annetine/Nathan Rosenberg, "The dynamics of technological change in medicine", Health Affairs 13 (1994) 28-46

Goto, Goro, Nihon hoshasen igakushiko (Tokyo 1969-1970)

103 Historical statistics of Japan, online database, www.stat.go.jp/english/data/chouki/index.htm (accessed 20 March 2010), 24-26 and 24-28.

104 Ministry of Health 1960.

105 In 2007, Japan had a rate of 92.6 computed tomography (TC) equipment for one million inhabitants, ahead of Australia (45.3), USA (32.2) and Korea (32.2). As for MRI equipment, Japan was in first place here as well, with a rate of 40.1, well ahead of the USA (26.6) and Australia (20.3). Onishi 2009, 3-5. 
Hitachi Seisakujo shi (Tokyo 1960)

Holtzmann Kevles, Bettyann, Naked to the Bone: Medical Imaging in the Twentieth Century (New Brunswick 1997)

Howell, Joel, Technology in the Hospital. Transforming patient care in the early twentieth century (Baltimore/London 1995)

Ikai, Shuhei, Byoin no seiki no riron (Tokyo 2010)

Isei hyakunen shi (Tokyo 1976)

Kees, Boersma, “Tensions within an Industrial Research Laboratory: The Philips Laboratory's X-Ray Department between the Wars", Enterprise \& Society 4 (2003) 65-98

Kudo,Akira/Tajima Nobuo/Erich Pauer (eds), Japan and Germany:Two Latecomers to the World Stage, 1890-1945 (Kent 2009)

Löwy, Ilana (ed.), Medicine and Change: Historical and Sociological Studies of Medical Innovation (Paris/London 1993)

Matsushita, Denkichi (ed.), Kindai nihon keizaijin taikei (Tokyo 1940)

Ministry of Finance, Dainihon gaikoku boeki (Tokyo 1907-1939)

Ministry of Health, Iryo setsubi chosa (Tokyo 1953-1960)

Miwa, Ryoichi/Akira Hara (eds), Kingendai nihon keizaishi yoran (Tokyo 2007)

Nihon choki tokei soran (Tokyo 2006)

Onishi, Masao, Hoshasen iryo: CT shindan kara kanwa kea made (Tokyo 2009)

Pasveer, Bernike, "Knowledge of shadows: the introduction of X-ray images in medicine", Sociology of Health and Illness 11 (1989) 360-381

Pickstone, John, Ways of knowing. A new history of science, technology and medicine (Manchester 2000)

Rosner, David, A once charitable enterprise. Hospitals and health care in Brooklyn and New York, 1885-1915 (Cambridge 1982)

Schlich, Thomas, Surgery, Science and Industry: A revolution in fracture care, 1950s-1990s (Basingstoke 2002)

Shimadzu Seisakujo shi (Kyoto 1967)

Shinmura, Taku (ed.), Nihon iryoshi (Tokyo 2006)

Shiraimatsu sogyo 130 shunen kinen (Osaka 2002)

Siemens, Georg, History of the House of Siemens (Freiburg/München 1957)

Stanton, Jennifer, "Making Sense of Technologies in Medicine", Social History of Medicine 12 (1999) 437-448

Stanton, Jennifer (ed.), Innovations in Health and Medicine. Diffusion and Resistance in the Twentieth Century (London 2002)

Stanton, Jennifer, "The diffusion of two renal analysis modalities in the UK, 1960s-1980s", in: Jennifer Stanton (ed.), Innovations in Health and Medicine. Diffusion and resistance in the twentieth century (London 2002b) 145-168

Sugaya, Akira, Nihon no byoin: sono ayumi to mondaiten (Tokyo 1981)

Tokkyo bunrui betsu somokuroku (Tokyo 1958)

Tokyo shibaura denki kabushiki kaisha 85 nen shi (Tokyo 1963)

Toseki (Kyoto 1977)

Tsukisawa, Miyoko, "Meiji shoto nihon ni okeru iryo gijutsu no inyu - shuyo katei: geka kigu ikuraseuru to shoshaku denkiki wo chushin ni", Nihon ishigaku zasshi 55/3 (2009) 317-328

Yamada, Katsuhiko, "Nakabori Kouji meiyo komon no goseikyo wo shinonde", Japanese Journal of Radiological Technology 61/9 (2005) 2

Yamashita, Mai, Iyaku wo kindaika shita kenkyu to senryaku (Tokyo 2010)

Yamazaki, Hiroaki (ed.), Nihon keieishi no kiso chishiki (Tokyo 2004)

Yongue, Julia, "Origins of Innovation in the Japanese Pharmaceutical Industry: The Case of Yamanouchi Pharmaceutical Company (1923-1976)", Japanese Research in Business History 22 (2005) 109-135

35 nen shi (Tokyo 1984)

262 Gesnerus $67(2010)$ 